MK Mahlakeng

Junior Lecturer (Units),

Department of Political

Studies and Governance,

Faculty of the Humanities,

University of the

Free State. E-mail:

mahlakengmk@ufs.ac.za

Hussein Solomon

Senior Professor,

Department of Political

Studies and Governance,

Faculty of the Humanities,

University of the Free

State. E-mail: solomonh@

ufs.ac.za

DOI: https://dx.doi.

org/10.18820/24150509/

JCH42.v2.9

ISSN 0258-2422 (Print)

ISSN 2415-0509 (Online)

Journal for Contemporary

History

2017 42(2):180-207

(C) UV/UFS

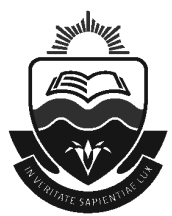

\section{AN ANALYSIS OF REGIME \\ CAPACITY AND A NASCENT \\ ENVIRONMENTAL CONFLICT IN \\ THE NIGER RIVER BASIN}

\begin{abstract}
The Niger River Basin (RNB) is and has been important to the cultural and socio-economic development of the West African region. However, the basin, which is home to some of the poorest countries in the world, might be experiencing a new landscape of conflict with water resources being a key factor. A combination of climate change, human population growth and unsustainable resource use is threatening the RNB. The purpose of this article is to determine, through the Homer-Dixon Environmental Scarcity Theory, the impact and effects of environmental scarcity in contributing to a nascent conflict in the RNB. The article conceptualises HomerDixon's Environmental Scarcity Theory as a theory that argues for the potential of conflict in transboundary river basins as a result of environmental scarcity. Furthermore, the article conceptualises Regime Theory, particularly in the RNB, as treaties on international rivers that hold essential norms and encourage rule-based cooperation to politically resolve problems and conflict in the field of international river basin management. The article will therefore use Regime Theory to examine the existence and formation, role and progress (i.e. successes and challenges) of the regimes and/or institutional mechanisms that aim to deal with environmental scarcity in the RNB.
\end{abstract}

Keywords: Niger River Basin (NRB); Homer-Dixon Environmental Scarcity Theory; Regime Theory; environmental scarcity; environmental conflict; regime capacity; Niger Basin Authority.

Sleutelwoorde: Nigerrivier-vallei; Homer-Dixon Omgewingskaarsteteorie; Regime-teorie; omgewingskaarstes; omgewingskonflik; regimekapasiteit; Nigervallei-owerheid.

\section{INTRODUCTION}

The Niger River Basin (RNB) is and has been important to the cultural and socio-economic development of the West African region (FAO 2002:1). It is also an important lifeline for large parts of the Sahelian region (Wetlands International Africa 2012). However, the basin, which is home to some of the poorest countries in the world, might 
be experiencing a new landscape of conflict with water resources being a key factor (Michel and Passarelli 2014).

A combination of climate change, human population growth and unsustainable resource use is threatening the RNB (Jagow-Schultz 2017). This is in addition to hydropower projects and extensive irrigation schemes which all affect the flow of the RNB (Wetlands International Africa 2012). Because the river is an important source of freshwater in this arid region, a coherent management agreement is needed between the riparian nations (Centre for Ecology and Hydrology 2017).

The aim of the article is to discuss hydropolitics in the RNB. Firstly, the article, through Homer-Dixon's Environmental Scarcity Theory, will focus on the growth in the rate of environmental scarcity (i.e. the change in the hydrologic system) in the RNB and its impact on societies, institutions and states in contributing to social breakdown and violence. And secondly, the article, through Regime Theory, will focus on the institutional capacity (i.e. regimes) in the basin to absorb environmental scarcity, thus alleviating a nascent environmental conflict in the RNB. Regime Theory is essential in outlining how institutions, particularly water regimes, can address transboundary challenges, thus fostering transboundary cooperation between riparian states.

\section{DESCRIPTION OF THE NIGER RIVER BASIN}

The Niger River, located in West Africa, is the third longest river in Africa after the Nile and the Congo. The river flows for $4,200 \mathrm{~km}$ from its source in the Guinea Highlands, within the humid tropics, through Mali and Niger with their semi-arid Sahelian climates, to the Niger Delta in Nigeria (Abebe 2009:122). The drainage basin covers a surface area of just over 2,2 million $\mathrm{km}^{2}$, extending into ten countries (see Map 3) (i.e. Guinea, Côte d'Ivoire, Mali, Burkina Faso, Algeria, Benin, Niger, Chad, Cameroon and Nigeria), with $76 \%$ of its area located in just three countries (i.e. Mali, Niger and Nigeria) (Aich et al. 2016:3). Since the RNB is shared by ten countries, water resources management is coordinated at an international level by the Niger Basin Authority (NBA) (Goulden and Few 2011:21).

According to Mahé, Liénou and Adeaga (2009:7-8), from the stand point of water resources, the Niger Basin can be divided into four zones: firstly, the Upper Niger Basin which is found in Mali, Guinea, and the Ivory Coast; secondly, the Inland Delta, which is entirely situated in Mali; thirdly, the Middle Niger Basin which lies within Mali, Niger, Benin; and lastly, the Lower Niger Basin which lies between Cameroon, Nigeria and Chad (Mahé et al. 2009:7-8). The RNB's main tributary is the Benue River (Jagow-Schultz 2017). 
Map 1: Map of the Niger River Basin

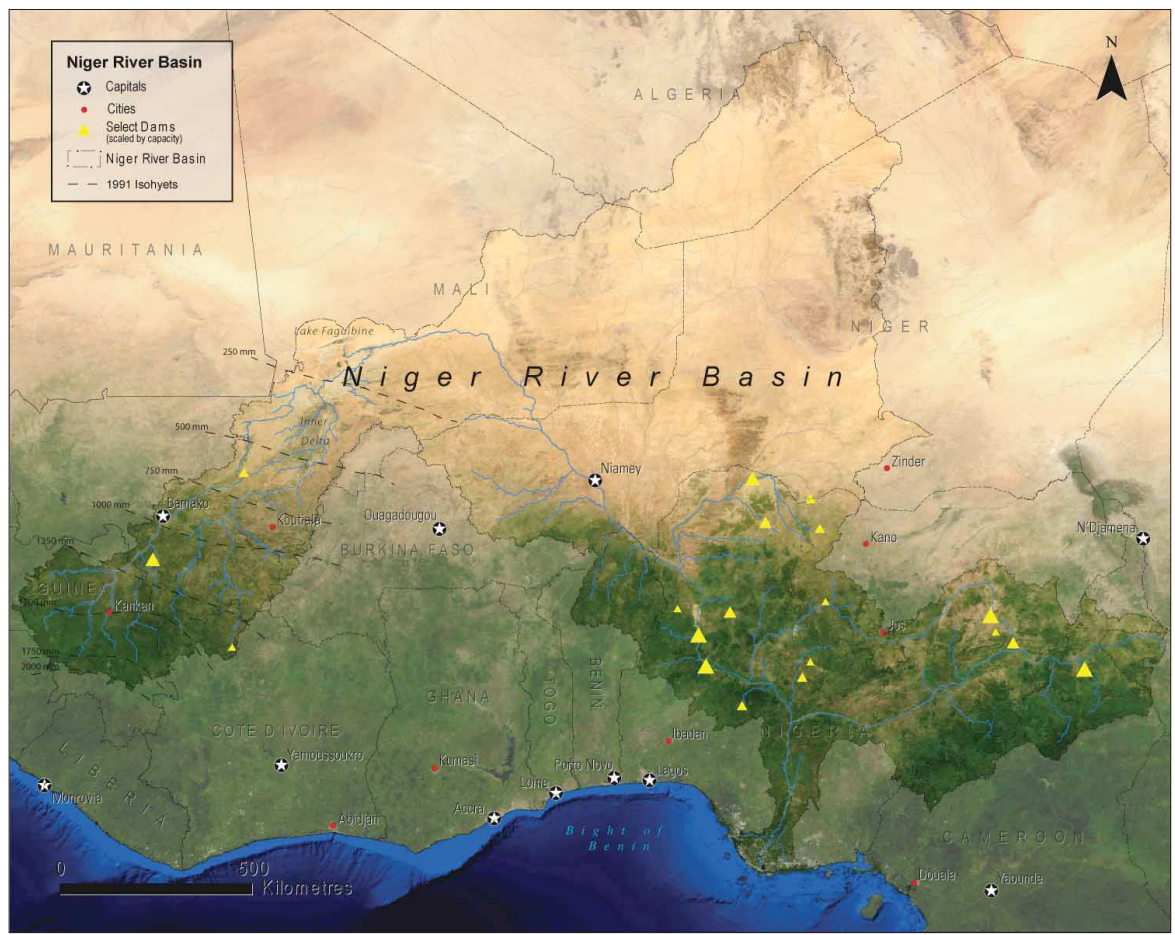

Source: UNEP 2010:60

\section{THEORETICAL FRAMEWORK: HOMER-DIXON ENVIRONMENTAL SCARCITY THEORY AND REGIME THEORY}

\subsection{Homer-Dixon Environmental Scarcity Theory}

The assumption behind Homer-Dixon's environmental scarcity approach is that, "resource scarcity, through the three causal forms of scarcity (i.e. demandinduced, supply-induced and structural-induced scarcity), have the potential to cause conflict" (Homer-Dixon 1999:8, 177; Cabot 2017:47).

\subsubsection{Demand-induced scarcity: Population growth affecting water resources}

According to Homer-Dixon (1999:51), demand-induced scarcity is a result of population size multiplied by per capita demand for a given resource, and an increase in either population or per capita demand increases total resource 
demand. Homer-Dixon (1999:52) argues that the growing population and greater per capita resource demand can simultaneously boost demand-induced and supply-induced scarcity. For example, increased population size and increased per capita demand for a given resource can have dual effects on environmental scarcity. On the one hand, they both increase the demand for the resource, and on the other hand they can both decrease supply by contributing to resource depletion and degradation (Homer-Dixon 1999:52). Demand-induced scarcity may lay the foundation for conflict in the absence of effective regimes (Van Schaik and Dinnissen 2014:33).

\subsubsection{Supply-induced scarcity: Degradation and depletion of water resources}

Central to Homer-Dixon and Blitt's (1998:6) analysis of the environment and conflict linkages is the idea that environmental change is only one of three primary sources of renewable resource scarcity. When environmental conflicts break out, it is usually against the background of a number of different factors interacting with one another. A number of scholars have asserted that largescale human-induced environmental pressures may seriously affect national and international security (Homer-Dixon 1991:76).

The decline in resources as a result of unsustainable use is fundamental in causing supply-induced scarcity (Urdal 2008:593). According to supplyinduced scarcity, this decline, or drop of a resource, means that there has been a decrease in the quality and quantity of the resource (Homer-Dixon 1999:48). The supposed decline, which ultimately leads to scarcity, refers to an environmental degradation. Environmental degradation reduces the quality and quantity of a limited resource, thereby decreasing the available supply to meet the growing demand (Bingham 2001). Environmental security literature stipulates that the degradation of the environment caused by supply-induced scarcity is seen globally to be a source of conflict (Homer-Dixon 1999:63-77). The main idea, proposed by Homer-Dixon, is that environmental degradation causes resource scarcity which eventually generates competition and conflict.

\subsubsection{Structural-induced scarcity: Uneven distribution of water resources}

The third kind of environmental scarcity is structural scarcity (Homer-Dixon 1999:52). In resource capture, demand- and supply-induced scarcities interact to produce structural scarcities (Kameri-Mbote 2005:2). This scarcity is caused by unequal distribution that concentrates a resource in the hands of some groups, and subjects the rest to greater than average scarcity (HomerDixon 1999:52). This form of scarcity is caused by an uneven resource distribution (Bingham 2001). Structural-induced scarcity occurs when one group is structurally denied equal access, through regimes and/or institutions, to a shared key resource by another (UNIFTPA 2012:9, 31). This means that scarcity of a resource would not occur if that resource was equally distributed 
(Urdal 2008:593). Therefore, the unequal distribution of water has instigated clashes (Kreamer 2012:90). More so, according to Homer-Dixon (1999:48; Homer-Dixon and Blitt 1998:6) these clashes over access to water may lead to conflicts.

\subsection{Regime Theory}

An important factor for enhancing and addressing both the management and distribution of transboundary river basins is the implementation of institutional support structures. Godana (1985:264) posits that basin states can only gain through the creation of a comprehensive commission serving as an institutional vehicle for cooperation. Moreover, the equitable development of transboundary river basins requires either an international institutional structure or a negotiated multilateral treaty regime as a bargaining tool between upstream and downstream countries (Okoth-Owiro 2004:24). Without these organisations, political tensions and disputes along shared rivers tend to emerge (Kukk and Deese 1996:22). Depletion, degradation, political tensions and disputes emerge in many transboundary basins due to a lack of capacity and capability at the mediating river basin organisation (Godana 1985:264). The concepts "regimes" and "institutions" are comparable. They both refer to established rules that govern behaviour (Raadgever 2005:3).

A widely accepted definition of an international regime is sets of implicit or explicit principles, norms, rules and decision-making procedures around which actors' expectations converge in a given area of international relations (Krasner 1983:2; Keohane 1989:3). According to Lindemann (2009:700-1), water regimes, on the other hand, are treaties on international rivers defined as norm and rule based cooperation for the political resolution of problems and conflict in the field of international river basin management.

According to most liberal scholars, the main role of institutions is to mediate conflicting interests between states over shared resources, in order to achieve cooperation. If regimes are established and backed up by political will, then the threat and impact of environmental scarcity can be avoided. Having regimes, institutions and treaties is not the same as having these regimes resolve specific problems. It is of no value to have regimes if there is no political will to pursue certain strategies aimed at specific problems.

One of the most important aspects of regimes is norm convergence, which helps states to behave in a common manner, thus making cooperation possible. The general expectation is that cooperation between riparian states will bolster adaptive capacity by allowing them to recognise (through the collection, exchange and use of data) and respond to (through joint planning and policy implementation) changing circumstances in the basin (Kistin 2012:41). Regimes serve as rules (formal or informal) that constrain and regulate state behaviour. 
The political will of regime member countries is imperative to enhancing regime and/or institutional capacity, thus countering the threat of regimes weakening or collapsing. Political will also include, and relies heavily on, member states financing the regime (Raadgever et al. 2008:5). According to Wolf (1998:261), without a good financing system, transboundary river basin management is not viable in the long run. Too much dependence on donors and banks makes management vulnerable.

\section{THEORETICAL APPLICATION}

In support of both Homer-Dixon's Environmental Scarcity Theory and Regime Theory, this section provides a theoretical application to the RNB.

\subsection{Homer-Dixon Environmental Scarcity Theory}

This section will apply Homer-Dixon's environmental scarcity theoretical perspective to determine the growth in the rate of environmental scarcity in the RNB. Moreover, it will further determine the potential of conflict in the RNB as a result of environmental scarcity.

\subsubsection{Demand-induced scarcity: Population growth in the RNB}

The Niger Basin is inhabited by 120 million people across 11 countries (Blumstein 2016). Homer-Dixon (1999:52) argues that such an increase in population size will undoubtedly increase the demand for land and water resources in the basin, while simultaneously decreasing supply by contributing to resource depletion and degradation. This is also in addition to an increased per capita demand that will be associated with the growing population (Homer-Dixon 1999:52). 190 Million people live in Nigeria (Worldometers 2017a), 18 million in Mali (Worldometers 2017b) and just over 20 million in Niger (Worldometers 2017c).

The RNB area is one of the most impoverished in the world with all of the countries, except Cameroon, having more than $50 \%$ of their populations living below the poverty line. This makes it extremely difficult for development to occur in the region (World Hunger 2015). Moreover, more than half of these people will be living in the cities within the next 15 years (Michel and Passarelli 2014). The exploding urban population growth means that certain challenges related to water will occur and certainly affect the sustainability of human urban settlements. These include the lack of access to safe water and sanitation and an increase in water-related disasters, such as floods and droughts. The scarcity of water has had a huge impact on the cities due to insufficient provision of water for domestic use, such as sanitation (UNDESA 2015). 
The Niger Basin is at the centre of an important migration flow from north to south due to economic differences and the demand for labour. The poorer and drier countries of Burkina Faso, Chad, Mali and Niger export their labour to the coastal and wetter countries of Nigeria, Côte d'Ivoire, Benin and Cameroon, largely for the production of cash crops (including coffee, cocoa and bananas). To a lesser extent, there is also the migration of the Bozo and Somono fishermen to the large reservoirs on the RNB, and of pastoralists with their stock to the Inland Delta in the dry season (Andersen et al. 2005:66).

Migration and large-scale demographic movements have largely developed in response to the river and the seasons, with herders moving their cattle, and sedentary farmers relying on the bounty of the Inland Delta and flowrecession agriculture to raise their crops. With an increasing population growth in the Niger Basin, pressure on existing resources has increased dramatically, leading in places to resource conflicts (Andersen et al. 2005:66). Moreover, rural populations throughout the region have traditionally responded to changing resource availability by migration (Michel and Passarelli 2014). The HomerDixon Environmental Scarcity Theory indicates that environmental scarcity or changing weather patterns will produce environmental refugees; people who are forced to leave their home region due to sudden or long-term changes to their local environment which compromise their well-being or secure livelihood.

Migration, however, as a result of environmental scarcity is not much of a good adaptive strategy, as indicated by Homer-Dixon's Environmental Scarcity Theory's "ecological marginalisation" perspective. This is due to the fact that high population densities in specific areas, as a result of migration, combined with a lack of knowledge and capital to protect local resources, will cause severe environmental damage, chronic poverty and violent disputes (Homer-Dixon 1999:15).

The demand for water for various purposes and use has prompted riparian countries to develop the basin. According to Wetlands International Africa (2012), the critical water flow of the Niger is ever more under stress from dam infrastructure for hydropower and extensive irrigation schemes. Dams in the Upper Niger in Guinea Conakry and Southern Mai off-take large amounts of water destined for the Inner Niger Delta. Today, there are fewer than 150 large dams in West Africa out of a total of 1,300 on the continent. The region has fewer than two large dams per $100,000 \mathrm{~km}^{2}$, as compared to 4,3 dams per $100,000 \mathrm{~km}^{2}$ in Africa as a whole. The Niger Basin has 27 major dams and over 5000 small dams. Many projects, especially multi-purpose ones, are being initiated. In most cases, the projects are conceived only at national level, even though the "purpose" of the dam is essentially regional, and the construction of a structure has, by definition, consequences beyond its borders. These consequences include changes in the hydrologic regime of the river, destruction 
of natural habitats and the agricultural production and ecosystem services that provide for livelihoods and food security (Ayuba 2016:14).

The lack of a shared vision and a Sustainable Development Action Plan (SDAP), has led to these unilateral projects to have a negative environmental and socio-economic impact on other riparian countries downstream (Olomoda 2002:22). The development of new dams does not only raise ecological concerns, but are also provoking difficult negotiations over equitably sharing the resources (Diarra 2011). This problem, combined with a lack of shared visions, will hinder development and makes the potential for conflict among basin users real (Olomoda 2002:22).

\subsubsection{Supply-induced scarcity: Degradation and depletion of water resources in the RNB}

The degradation of water quality is a significant problem for the Niger (Andersen et al. 2005:56). The RNB is one of 11 African international river basins, more than half of which are approaching or are already under situations of water stress at basin level (Goulden and Few 2011:6). According to Beekman (2005:35), this crisis has, therefore, led to competition between the Niger water users over already limited water resources.

Competition over scarce water resources is increasingly a source of tension in the Niger Basin (Abebe 2009:123). There is increasing water use in the RNB, resulting from agriculture, domestic use and hydropower (Beekman 2005:36). This has led to the degradation of the environment because of low river flows, sedimentation of river beds directly related to deforestation and over-farming of fragile soils, industrial and household pollution, and loss of arable and pasture lands (Abebe 2009:123). Pollution caused by these factors is making the Niger's water increasingly unusable (Beekman 2005:35; Simpkins 2010).

For the most part, cities along the river have not developed collection and treatment plants for either industrial or domestic wastewater. In addition to urban pollution sources, agricultural runoff, particularly fertilizers, have been found at several sites. At the coastal delta, oil production has been the source of a host of environmental issues. Millions of barrels of oil have been spilled in the delta's oil producing region (UNEP 2010:62). According to Phil Vernon, International Alert's Director of Programs for Africa and Peacebuilding Issues, "You've got vulnerable people, vulnerable households, vulnerable communities living within [...] fragile systems, governance systems, [and] environmental systems" (Diamond 2011).

The scarcity of water in the Niger Basin has thus led to conflict between farmers and herders (FAO 2002:1). Furthermore, Michel and Passarelli (2014) assert that these environmental pressures and resource scarcity in the Niger region have also played a part in producing widespread insecurity and militancy in the region, which have emerged as a result of a dearth of economic opportunities due to dwindling resources. They blame the 2013 radicalism of the 
Islamic terrorist groups (i.e. Ansar al-Dine and the Movement for Unity and Jihad in West Africa (MUJAO)) associated with Al Qaeda in Mali and the emergence of Boko Haram in neighbouring Nigeria, to resource scarcity.

Firstly, they assert that, in Mali, these radical Islamist factions were able to seize control of much of the nation's territory by exploiting a pre-existing revolt among the region's Tuareg peoples, first absorbing and then displacing the Tuareg insurgent forces. Crucially, this long-standing Tuareg rebellion first arose in part from the perceived indifference or inability of a distant central government to provide relief to Tuareg regions plagued by sustained drought in the 1970s and 1980s. Bamako eventually dampened this initial rebellion with formal peace negotiations and promises of development, but assistance proved slow and the north remained marginalized, while Tuareg grievances continued and the insurgency ultimately returned (Michel and Passarelli 2014).

In neighbouring Nigeria many observers, such as the International Crisis Group, link the rise of Boko Haram to the decline of the once-dominant agricultural sector in Nigeria's impoverished northern states, and popular frustrations at government failures to deliver water, energy, roads, and other services. With faltering agriculture and feeble infrastructure hobbling the northern economy, poverty and unemployment have rendered the region's youth more vulnerable to Islamic radicalisation and Boko Haram recruitment. Worse, the instability in Nigeria has now come full circle, threatening to deepen the cycle of insecurity as violence in the northern states further depresses agricultural production, disrupting harvests and displacing farmers fleeing the fighting (Michel and Passarelli 2014). Although these tensions and conflicts are localised, the potential of water scarcity to intensify these conflicts beyond borders should not be underestimated. Michel and Passarelli (2014) further argue that climate change will inevitably make the environmental situation worse.

Much of the Niger Basin is in a region of low rainfall, with high natural variability in rainfall and stream flows that affect land and water resources and people's livelihoods (Goulden and Few 2011:5-6). Climate variability is manifested both in seasonal variations in rainfall over the basin and year-to-year variability in rainfall. In some years, this variability is manifested as extreme events. Extreme events include droughts, which are recurrent in many parts of the basin, but also severe flood events with major impacts on lives, livelihoods, wellbeing and the productivity of sectors (Goulden and Few 2011:45). Drought and reduced water availability have forced rural communities, notably farming and cattle-herding families, to migrate south to more humid conditions, increasing pressure on the remaining depleted floodplains, wetlands and arable land (Abebe 2009:123). The ensuing intensity of competition has already caused localised conflict in semi-arid zones. There are signs of disputes taking place based on ethnic dimensions as hardships are blamed by indigenous groups on 
"outsiders", rather than affected communities seeing their difficulties as shared "conflicts of interests" (Abebe 2009:123).

The Niger Basin was seriously affected by recurrent severe droughts, particularly over the periods 1968-1973, 1982-1985 and 1990-1991, which caused great distress in the region (Amadou et al. 2014:3). The Sahel, the area just south of the Sahara, serves as the best example of the effects of severe droughts caused by climate change. The Sahel has experienced the worst effects of water scarcity, hotter temperatures and longer dry seasons (UN 2007:18). For instance, In the 1970s and 1980s, the Sahelian droughts extended over the Niger Basin, causing famine, forcing dislocation of people and destroying livelihoods. A period of reduced rainfall across the Sahel began in the early 1970 s and continued through to the 1990s, with two periods of very severe drought in the early 1970s and early 1980s (UNEP 2010:62).

Nigerian President Mohammadu Buhari said the basin is experiencing significant degradation of its resources under the combined effects of climate and human activities. The President noted that the phenomenon is, "heavily compromising the future of the ever-increasing populations of the basin through the intensity and number of environmental, social and economic problems it is inducing". These developments may well be exacerbated by the lack of state and regional capacity to manage the effects of climate change (Wers and Conley 2012:3). President Buhari, represented by the Minister of Environment, Ms Amina Mohammed, said part of processes to achieving a shared vision for the sustainable development of the basin led to the establishment of three important action plans: firstly, the Sustainable Development Action Plan of the Basin (2008-2012); secondly, the newly adopted 2016-2024 Operational Plan; and lastly, the Climate Resilience Investment Plan, expected to gulp $\$ 7,2$ billion (National Mirror 2016).

Mali, Niger and Nigeria have all taken steps at national level to implement planning for adaptation to climate change. Mali and Niger have produced National Adaptation Programmes of Action (NAPAs), supported by the United Nations Development Programme (UNDP) and the Global Environment Facility (GEF). This is a requirement for all Least Developed Countries that are signatories of the United Nations Framework Convention on Climate Change (UNFCCC) (Goulden and Few 2011:22).

Mali's NAPA, led by the Ministry of Environment, was completed in 2007 and supported by UNDP. Niger's NAPA was completed in 2006, led by the National Environmental Council for Sustainable Development with funding provided by GEF. Nigeria, since it is not classified as a Least Developed Country, was not required to produce a NAPA. Nonetheless, with the support of UNDP and the Canadian International Development Agency (CIDA), it began producing a similar document in 2010 which it has called its National Adaptation Strategy and Plan of Action (NASPA), to be finalised by the end of 2011 (Goulden and 
Few 2011:22-23). According to the London School of Economic and Political Science (LSE) (2015), these efforts resulted in the publication of the National Adaptation Strategy and Plan of Action on Climate Change for Nigeria (NASPA-CNN) in 2011. The Strategy outlines responses to climate change in key areas, such as agriculture (crops and livestock), freshwater resources, coastal water resources and fisheries, forests, biodiversity, health and sanitation, human settlements and housing, energy, transportation and communications, industry and commerce, disaster, migration and security, livelihoods, vulnerable groups, and education. However, the policy document did not receive official support. Instead, in 2012 the Executive Council approved the adoption of a National Climate Change Policy and Response Strategy (NCCP-RS). NCCP-RS aims to provide a framework for responding to climate change-induced challenges, such as increased flooding and rising sea levels. There are also plans to create a National Strategic Climate Change Trust Fund and to construct a National Appropriate Mitigation Action document. In 2013, a National Policy on Climate Change was finally approved and adopted by the Federal Executive Council. This forms the basis for any new climate change law (LSE 2015).

\subsubsection{Structural-induced scarcity: Uneven distribution of water resources in the RNB}

The analysis of the RNB, as far as Homer-Dixon's Environmental Scarcity Theory is concerned, is highly important due to the fact that structural-induced scarcity (i.e. the uneven distribution of water resources) is not driven by regimes. Uneven distribution of water resources in the RNB is a result of the existence and interaction of demand and supply-induced scarcities.

The RNB case will enable the article to illustrate the theory's notion that the interaction of demand and supply-induced scarcity can produce structuralinduced scarcity. Moreover, this will justify the notion stated by the theory that these three forms of scarcity are not mutually exclusive, and the interaction of the other has the likelihood of instigating the occurrence of another. Structuralinduced scarcity in the Niger can occur as a result of "resource capture", which will be influenced by the depletion of resources as a result of population growth and the unsustainable use of water resources.

The Homer-Dixon Environmental Scarcity Theory indicates that, when powerful groups within a society recognise that a key shared resource is becoming scarcer (due to both supply and demand pressures), they will use their power in their favour to manipulate regimes governing resource access, thereby accumulating more resources at the expense of other riparian countries (HomerDixon 1999:15). Homer-Dixon (1999:74) further argues that "greed", and "fear" of the disadvantage that rising scarcity might produce, can be a motivation.

The existence of dams on the river, when combined with climate variability, has caused misunderstandings between countries sharing the river in the past 
(Goulden and Few 2011:21). In West Africa, as the number of large dam projects increases, the level of interdependency of countries continues and, as availability of water reduces, a fertile ground for misunderstanding and tension among countries is created. Examples include Senegal and Mauritania in June 2000 (IRIN News 2000); Burkina Faso and Ghana in 1998, when the increase of water use by Burkina Faso reduced the amount of water going to the Akosombo hydroelectric power station (Gao 2010); Benin and Niger, over the sovereignty of Lete Island, the meeting-place of nomad pastoralists from Niger, who settle there seasonally, and sedentary farmers from Benin (IRIN News 2015); Niger and Nigeria when Niger constructed dams, thereby reducing water flow to Nigeria which has large dams for hydro agricultural and energy (Sahel Standard 2015); and Cameroon and Nigeria, where the "migration of Lake Chad" attracted Nigerian immigrants to the Cameroonian part of the lake (Youssef 2016).

According to Diarra (2011), the new dams not only raise ecological concerns, but are also complicating negotiation processes over equitably sharing. This is a result of divergent interests of riparian countries. Moreover, ecologists fear that new dams will have damaging effects, such as uneven distribution downstream, particularly for the more than one million people who live in the Inner Niger Delta in Mali. For instance, large-scale irrigation projects and hydroelectric dams have caused the water level in the Niger fertile and ecologically-diverse wetland to fall by more than $20 \mathrm{~cm}$, shrinking the annuallyflooded area by 900 square kilometres. According to Blumstein (2016), the construction of dams affects water levels which ultimately impact on people depending on fisheries, rice production or livestock. Furthermore, the decrease in water levels means that the navigation of the river would also be constrained, since the water would no longer be deep enough for large boats (Diarra 2011).

Blumstein (2016) argues that existing competition over natural resources and local conflicts could, therefore, grow as a result of environmental change caused by both natural and human activities. Wirth (1989:10) argued that environmental change may shift the balance of power between states, thus producing instabilities that may lead to war. Moreover, Blumstein (2016) argues that this could further destabilise a region which is already characterised by high political instability. Diamond (2011) blames the worsening tensions in the Basin on poor policy decisions. This also calls for the modification of environmental laws and regulations in the region to address the aforementioned environmental problems in the basin (Beekman 2005:38). Therefore, regime-based interstate cooperation is a reality that is in need of an explanation.

Given the existence of the three forms of scarcity in the Niger Basin and their argued potential to lead to a nascent environmental conflict, it is therefore important to analyse the formation and capacity of regimes in the basin to address environmental scarcity, and thus avoid bourgeoning environmental conflicts in the basin. 


\subsection{Regime Theory}

This section will use Regime Theory to examine the existence and formation, role and progress (i.e. successes and challenges) of the regimes and/or institutional mechanisms that aim to deal with the development, sustainability and utilisation of the RNB. The catchment areas, covering several countries, similar to the Niger Basin, requires a binding agreement for cooperation among the riparian countries (Olomoda 2002:13). A common approach to river basin development has been to develop "River Basin Master Plans". This makes sense, because such a comprehensive approach facilitates a broad and holistic development plan (Andersen et al. 2005:59).

The nine RNB countries which form part of the Basin's Inter-Governmental Organisation $^{1}$ are among the poorest countries in the world. Four of the nine Basin countries are among the bottom 20 countries on the World Development Indicators (WDI) scale, while on the UNDP's Human Development Index (HDI), seven countries are among the bottom 20, with Niger having the lowest HDI in the world. The need for development and investment in the region is evident and, as the RNB holds tremendous potential, this is the reason for cooperation (Andersen et al. 2005:58). Furthermore, according to the World Bank (2015), the Niger Basin is by any measure one of the most fragile developing regions of the world.

When dealing with a shared river basin, and in the absence of an effective basin organisation, most countries will plan on a unilateral basis. In some river basins, member states have rushed to develop the basin through infrastructure projects, seeking to acquire rights ahead of any neighbouring states doing the same. The Nile River Basin is a case in point. In the absence of a cooperative agenda to which countries have committed and which clearly assigns benefits to each member state, the pursuit of unilateral development will most likely lead to lose-lose outcomes, the potential consequences of which include increased tension and insecurity among member states, and lost opportunities for regional cooperation and integration. For many years, the trend in each of the Niger Basin countries has been toward unilateral development of the river's resources. From the position of each nation state this makes perfect sense, particularly given the lack of a strong regional river basin institution through which cooperative developments could be leveraged, promoted and instituted (Andersen et al. 2005:63).

Beekman (2005:38) argued that the Niger has a poor legal framework at both the regional and national levels. It is also characterised by inadequate implementation of available regulatory instruments, such as supra-national

1 While a small area of Algeria falls within the Niger Basin, it is not a member of the NBA since it is neither a significant contributor, nor a major user of basin water (McKinney 2012). 
institutions created by riparian countries and responsive to a country's ministry in charge of water resources (Beekman 2005:38).

Efforts toward basin-level cooperation in the Niger Basin started with the 1963 Niamey Agreement (Act de Niamey) which defined the conditions of navigation on the RNB. The Agreement also called for economic cooperation between basin states. A year later, the RNB Commission (NRC) or Commission du Fleuve Niger (CFN) was established with the aim of promoting and coordinating studies of RNB resources with a view to their future development. In 1980, the Niger Basin Authority (NBA) was created with the mandate of speeding up interstate cooperation in the development of the basin resources. The mandate embraced water development, energy, transport/navigation, agriculture, fisheries, livestock production, forestry and industry. Faced with a situation of lethargy and unable to move forward its ambitious mandate, the NBA saw its convention revised in 1968, 1978, 1979, 1980 and 1987 (Niasse s.a.).

\subsubsection{Niamey Agreement concerning the River Niger Basin Commission and the navigation and transport on the Niger River}

The basin faces many environmental problems as evidenced above. However, the RNB has potential for a spectrum of development uses, including domestic and industrial water supply, flood control, hydropower generation, irrigation, fisheries, navigation and tourism (UN - Treaty Series 1984:209). Just after independence in the early 60s, inspired by the Tennessee Valley Authority (Waterwiki.net 2009), the Niger riparian countries came together to develop a binding agreement to form the RNB Commission (NRC) for cooperation in the field of management and use of the water resources of the Niger. The NRC was initially formed to foster co-operation and promote sustainable development (Olomoda 2002:13).

The Convention during which these countries established the NRC took place in Niamey on 26 October 1963. A year later, on 25 November 1964, after many rounds of negotiations, an Agreement concerning the RNB Commission and the navigation and transport on the River Niger, also referred to as The Niamey Treaty was adopted (UN - Treaty Series 1967:23). Article 12 of the Agreement relating to agricultural and industrial utilization and development of the Niger Basin clearly states its aims with regard to the development, use and sustainability of the RNB. According to Article 12, "They undertake further to abstain from carrying out on the portion of the River, its tributaries and subtributaries subject to their jurisdiction any works likely to pollute the waters, or any modification likely to affect biological characteristics of its fauna and flora, without adequate notice to, and prior consultation with, the Commission" (UN - Treaty Series 1964:27).

This agreement led to the establishment of the NRC with the aim to manage and develop the RNB as set out in Article 1 of the agreement. According 
to Article 1, "There shall be established an Inter-Governmental Organization [...] which shall be called River Niger Commission" (UN - Treaty Series 1967:23). However, the NRC's functionality was poor. As a result, three Conventions, in 1968, 1973 and 1979, were established. At each Convention, respectively, the following statements about the objectives were issued. Firstly, the 1968 Convention aimed at forging a close cooperation between the member states for sound development of the basin-wide resources. Secondly, the 1973 Convention emphasised the freedom of navigation on the Niger River among member states. And lastly, the 1979 Convention aimed at equal access to the basin's water resources for all users (Olomoda 2002:13).

\subsubsection{Convention creating the Niger Basin Authority (with protocol relating to the Development Fund of the Niger Basin)}

In 1979, the 1964 Niamey Agreement was revised. This led to the adoption of The 1980 Convention creating the Niger Basin Authority (with protocol relating to the Development Fund of the Niger Basin. This meant that the NRC had been replaced by the NBA (i.e. from a "commission" to an "authority") in an attempt to give it an institutional and legal framework and, thus, to attract prospective donors and also regain the confidence of its member states (UN - Treaty Series 1984:209).

According to Article 21 of the 1980 Convention, "This Convention revises the Niamey Agreement, signed in Niamey on the 25th of November 1964, revised in Niamey on the 2nd of February 1968 and on the 15th June 1973, and in Lagos on the 26th January 1979" (UN - Treaty Series 1984:216). Although the Niamey Agreement was revised by the 1980 Convention, it committed itself to inherit the Niamey Agreements' duties and obligations. For instance, Article $1(3)$ of the 1980 Convention states that, "The Authority inherits all the assets and assumes all the obligations of the River Niger Commission" (UN - Treaty Series 1984:209).

After the adoption of the Niamey Convention and the creation of the NRC on 25 October 1964, the nine NBA member countries revised the NRC Convention several times to improve its institutional performance. When these revisions showed no result, the NBA was formed to replace the NRC (Olomoda 2002:17). The NBA is still headquartered in Niamey, Niger.

The preamble of the 1980 Convention states the reasons as to why the NRC had to be transformed into the NBA. The preamble states the need to further promote socio-economic progress and development in member states. Moreover, it seeks to reaffirm the willingness for unity and solidarity in the organisation for the overall development of the Niger Basin. As a result, the Summit of Heads of State and Government, which met on 26 January 1979 in Lagos, therefore decided to transform the River Niger Commission into a "Niger Basin Authority" (UN - Treaty Series 1984:209). 
The institutional and legal framework to carry out its mandate went between 1980 and 2001 through four phases. Phase I (1980-1986) saw the establishment of the Executive Secretariat. The most important assignment of this phase was to ensure that the aims and objectives set out in the 1980 Convention were achieved. This was possible through financial support from donors. However, problems such as institutional weakness and inadequate finance persisted and, as a result, it could not carry out the assignment given (Ayibotele 2008:1). Moreover, the NBA did not meet the expectations of the member states. Some of these states signified their intention to change their membership to observer status, while others merely attended the meetings with scepticism (Olomoda 2002:13).

Phase II (1987-1993) was to adopt a revised 1980 Convention to cure the policy shortcomings of the 1980 Convention, restructure the authority and adopt a five year development plan. As such, this phase saw the reformation of the NBA in order to focus on development and to strengthen it institutionally and financially. In addition to this, a "Revised Convention" was signed in 1987 which committed member states to acquaint themselves with development plans relating to aspects affecting the Niger Bain. Furthermore, they were also prohibited from carrying out any works on the section, tributaries and subtributaries of the river that are likely to pollute the Niger Basin. However, it failed to address the problems experienced in the first phase due to, most notably, lack of funds, resulting in the challenge of fulfilling the duties of this phase to compile essential data for long-term policy development (Ayibotele 2008:1)

In Phase III (1994-1997), the problems experienced in Phase I and II became worse, leaving the NBA without political and policy direction. This led to the Economic Commission for African States (ECA) stepping in and assisting. Finally, Phase IV (1998-2001) saw a resurgence of the NBA. Most importantly, in this phase, the Authority regained the confidence of the member states and its development partners (Ayibotele 2008:1-4).

The NBA is mandated to foster, promote and coordinate studies and programmes related to the basin. It is further required to promote cooperation among member countries and to ensure integrated development of resources, notably energy, water, agriculture, forestry, transport and communication. The NBA has worked to create an "Integrated Development Plan of the Basin", focusing on cross-boundary projects (Abebe 2009:125). Moreover, the Niger riparian countries realised that all of these are possible if well managed. These are imperative aspects of development as indicated in Article 3 of the "1980 Convention Creating the Niger Basin Authority (With Protocol Relating to the Development Fund of the Niger Basin)" which states that, "the aim of the Authority is to promote the cooperation among member states and to ensure an integrated development of the Niger Basin in all fields, by developing its resources, particularly in the fields of energy, water resources, agriculture, animal 
husbandry, fishing and fisheries, forestry and forestry exploitation, transport, communications and industry (UN - Treaty Series 1984:209).

One of the NBA's major initiatives was the adoption and implementation of a Sustainable Development Action Plan (SDAP), which most significantly involves managing several hydroelectric and agricultural dams built along the river. So if one riparian country wants to build a dam, it must take the plans to the NBA for a decision. Representatives from each of the Niger Basin countries form part of the NBA, so each country has an opportunity to comment on water resource development plans (Goulden and Few 2011:21).

In Abuja in February 2002, the Niger Basin Heads of State agreed to develop a management framework for the basin through preparation of a Shared Vision Process (Andersen et al. 2005:59). The Shared Vision Process was completed in 2008 (Talbi 2013). It lay out cooperative actions through which needs and priorities are defined and through which management, development and investment actions iare identified (Andersen et al. 2005:59).

The Shared Vision is an expression of the countries' commitment to promote a framework for enhancing cooperation and sharing benefits deriving from the Niger Basin's resources. The Shared Vision Process encompasses several objectives. The first objective is political aimed at formulating a statement on the sustainable development of the Niger Basin to be adopted by the Niger Basin Heads of State. Such a statement must include commitments to, and goals for, cooperation that will lead to joint developments in the basin. The second objective is operational, to prepare the SDAP for the Niger Basin. The SDAP is seen as an appropriate instrument to realise countries' commitment to address the challenges of the basin. It includes an innovative planning and priority-setting approach to define the development opportunities in which the member countries can jointly participate. The Shared Vision's third objective is financial, to mobilise resources from both member countries and international donor partners to implement the SDAP (Andersen et al. 2005:59).

The Shared Vision Process provides an opportunity for the nine member countries to reaffirm at the highest level of authority their willingness to collaborate and also to place a higher emphasis on new values, such as equitable access, sustainable development and public participation (Niasse s.a.). According to Talbi (2013), noticeable achievements as a result of the Shared Vision Process include:

- a 20-year Sustainable Development Action Plan for the basin 2007 was approved by the Council of Ministers of the NBA;

- a 20-year investment program for the basin and the Water Charter was approved in 2008 by the Heads of State and Government Summit, and

- $\quad$ the Water Charter was signed in 2009 and ratified in 2010. Also, Annexes to the Water Charter were prepared; the first adopted and signed in 2012. 
The NBA derives funds from member states and international donors and through participation in cooperative projects with organisations such as the World Wildlife Fund (WWF), Wetlands International, and foreign donor governments (Abebe 2009:125). Contradictory, President Buhari reiterated that the NBA faces the challenge of financial capacity as member states fail to fulfil their financial obligation (National Mirror 2016). This is a challenging factor confronting the organisation's capacity to execute imperative tasks relating to the development and management of the basin. It is a major reason why environmental issues continue to persist unabated. This is also despite provision provided for in Article 4 of the Convention. Article 4 of the 1980 Convention further committed itself, among other issues relating to water control and utilization, to regulate main waterway flow and drainage, control floods, prevent and control drought and desertification, and prevent soil erosion and sedimentation (UN - Treaty Series 1984:211). This is indicative of poor policy execution and implementation by member states. Furthermore, it signals the lack of political will by member states. It exposes the lack of capacity of the NBA to hold member states (signatories) accountable to actions hazardous to the Niger Basin that are committed in their respective countries.

\subsubsection{The 1987 revised Convention for the establishment of the Niger Basin Authority}

On 27 October 1987, the revised Convention for the restructuring of NBA was adopted, with three objectives in mind. Firstly, it aimed at harmonising and coordinate national development policies on basin wide resources. Secondly, the NBA's objective was to formulate a policy and implement an integrated plan to develop the basin, and lastly, the third objective was to design, build and maintain common structures and projects (Olomoda 2002:17; IEA 2016).

These objectives are all important, because to effectively and cooperatively counter the threat posed by environmental issues and effectively implement transboundary agreements in transboundary river basins, regime member countries' will have to harmonize national laws, implement integrated plans and establish common structures. Institutions can range from independent national bodies that coordinate policies to joint institutions that formally receive decisionmaking power from the respective national governments (Brels et al. 2008:13). Harmonisation is normally necessary as a means of avoiding some type of dispute due to water scarcity (Earle 2005:56).

Despite these new objectives, the organisation continued to face several operational and management difficulties. Some of these difficulties are due to inadequate political will to back the mandates, and of various economic, social and political problems back at home. Similarly, since the degree in which the countries share in the basin varies, with Nigeria having $30 \%$ and Chad $1 \%$, the riparians have different levels of interest and commitment in the development and 
management of the basin. However, in an attempt to find a balance with regard to an equitable and accommodative financial accountability of developing and managing the basin, a new sharing formula was proposed (Olomoda 2002:17).

In December 2000, the 6th Summit of Heads of State and Governments of the NBA member countries finally adopted a new formula for dues, heretofore shared more or less equally in past. The new formula gives the three greatest beneficiaries of Niger basin resources (Mali, Niger, Nigeria) a substantial increase in their shares, while the other member states receive corresponding budgetary relief. The new sharing formula ranges from $30 \%$ for Nigeria to $1 \%$ for Chad, which reduces the financial burden of the poorer nations (Olomoda 2002:20).

In addition to the creation of regimes in the Niger Basin, Niasse (s.a.) argues that there are also numerous agreements that were established between two or more states in sub-sections of the basin. Examples include the 1990 Agreement between Nigeria and Niger on the equitable sharing, conservation and development of their common water resources; the 1998 agreement between Niger and Mali relating to cooperation in the use of water resources of the Niger; the hydroecological management project of the Upper Niger between Guinea and Mali; and, the 2000 Nigeria-Cameroon Protocol Agreement aimed at coordinating the releases of water from dams. These agreements came after the establishment of the Niger Basin organisation. They highlight the relevance of the subsidiarity principle more than they challenge that of basin organisations. Furthermore, it is important to emphasise that, in at least one case (NigeriaCameroon Agreement), it is the basin organisation (NBA) that facilitated discussions between the two countries concerned (Niasse s.a.).

However, Olomoda (2002:22) maintains that despite several adoptions of agreements and the transformation of the NRC into the NBA, several major institutional problems still persist. These include:

- a lack of clearly defined objectives and suitable regional strategies based on a clear shared vision or master plan acceptable among riparian countries for the development of the basin;

- a lack of legal and institutional mechanisms for benefit-sharing for the prevention of water related conflicts;

- $\quad$ an inadequate framework for defining institutional objectives and policies;

- inadequate institutional and operational capacities for planning design and execution of projects;

- a lack of community involvement in the projects, from grass root project planning to their execution;

- a weak institutional capacity and vision for planning and co-ordinating the implemented action; 
- $\quad$ the non-cooperation between riparians or member countries; an insufficient mechanism for consultation among stockholders;

- a lack of adequate knowledge of national policy, activities and orientation of water resources project at national level; and

- a lack of co-operation and adequate consultation between institutions, intergovernmental organisations and donor agencies.

Although loss of water supplies physically manifest as local and regional problems, water scarcity by itself does not trigger war. The main issue that determines the emergence and/or deterrence of war is the governance of water. Governance failure and poor coping mechanisms can contribute to unrest and conflict (Abebe 2009:124). In addition, Homer-Dixon (1999:4-5) asserts that, given the poor financial, material and human capital in most regions, environmental scarcity can further exacerbate the fragility and poor capacity of political institutions and/or regimes.

\section{CONCLUDING REMARKS AND RECOMMENDATIONS}

\subsection{Concluding remarks}

In the Niger River Basin, where water scarcity and flow variability are always calls for concern, the only option for sustainability of the water resources, optimal utilization, and good member relationships is to pursue the path of coordinated, cooperative water resource development. It is important to note that, while environmental changes may play a role in setting the stage for conflict, the causal relationship is highly complex and the role of regimes and/or institutions are crucial in the emergence of conflict.

The article conceptualised the Homer-Dixon Environmental Scarcity Theory as a theory that argues for the potential of conflict in transboundary river basins due to environmental scarcity. Environmental scarcity is triggered by a combination of population growth and excessive strain on dwindling renewable resources, exacerbated by unequal access to that resource. Furthermore, the article conceptualised Regime Theory, particularly on transboundary basins, as treaties on international rivers that hold essential norms and encourage rule-based cooperation to politically resolve problems and conflict in the field of international river basin management.

Regime capacity in the RNB is promising, since there is a level of cooperation among riparian states an acceptance of regime authority. And this makes the development potential of these basins real and the avoidance of a nascent conflict in these basins respectively possible. This is a result of the participation of riparian states in institutions created to govern transboundary basins. The NBA has achieved a sense of full participation and membership of riparian countries, thus giving these regimes a legitimate, constituent and legal 
position to be operational over these basins. This means that the environmental challenges faced by these basins respectively have the potential of being adequately addressed in the near future.

Although the NBA will continue to face markedly high levels of environmental scarcity challenges threatening its capacity and stability, the regime capacity will remain resilient against the effects. The article draws support of this idea from the "institutional resiliency argument". The establishment of cooperative water regimes is key in ensuring the resilience of regimes. And this is also made possibly, as argued earlier, by full riparian membership and participation. However, lack of political support by the member countries of the NBA still remains a key issue. And this ultimately relates to greater lack of technical and financial support of the Authority.

In conclusion, it is important to note that, while environmental changes may play a role in setting the stage for conflict, the causal relationship is highly complex and the role of regimes and/or institutions are crucial in the emergence of conflict. Hydropolitics (the politics of water) is a function of two variables: the rate of environmental scarcity (the change in the hydrologic system); and the institutional capacity (regimes) to absorb that change.

\subsection{Recommendations}

Research on the relationship between environmental scarcity and conflict promises to be a significant future research area. Moreover, it is likely to promote further dialogue with political, social, economic, natural and security study scientists and academics, as well as policymakers. This article aims to contribute to the environment-conflict literature by arguing that the politics over water that pose the threat of leading to environmental conflicts are a result of both environmental scarcity and institutional capacity.

Africa is faced with various water-related issues that pose serious challenges to the peace and security discourse on the continent. These includes, among others, managing risks, improving the knowledge base, water for industry, and water for cities. These challenges pose as risk factors for a nascent environmental conflict between riparian states in the face of weak regimes. Moreover, the 2000 Hague Ministerial Declaration and the World Water Assessment Programme (WWAP) acknowledges the existence and impact of these challenges.

International best practices to finding solutions for short, medium and long term to de-escalate tensions and/or disputes and manage shared water resources, include both diplomatic and/or legal mechanisms which have been used to settle disputes, including in the water area. Firstly, improving the knowledge base about the negative impacts and positive benefits that water can bring will help in valuing water, and thus managing potential risks. This knowledge includes preserving water quality and quantity for domestic, industrial 
and agricultural use, less over-consumption and/or pumping, more sustainable hydropower, and the restoration of wetlands to enhance benefits.

Secondly, an important solution to inter-riparian disputes is the negotiation of inclusive agreements. These agreements can either be implicit or explicit, written or unwritten, and legally binding or not.

Thirdly, agreements and their successes are dependent on "institutions" being established. Given that institutions are referred to as "rules of the game" that define conduct and practice, riparian states must establish such rules. These rules may vary from operational rules and decision-making rules to constitutional rules which must define conduct and practice of regime member states in respective areas. This will also be imperative in guiding the interaction of member states amongst one another. Firstly, operational rules help in determining how much of the water should be allocated on the one hand, and the adverse impact and/or benefits of the construction of infrastructures. Secondly, decision-making rules help in determining operational rules. And this in particular enables the involvement of and participation of actors. And lastly, constitutional rules help to bestow and legitimises the power of decision-making by national governments. These rules enable the participation of member states in decisionmaking processes. Moreover, these rules enable for the conclusion of treaties and agreements.

Fourthly, riparian states need to identify water-related issues as a "collective problem". This will help in paving the way for an inclusive agreement to be reached, and will therefore enhance the potential for future collective gains and cooperation. It is much easier to achieve cooperation in situations where member states are able to realise that working collectively makes for a win-win situation to be possible.

Fifthly, "issue-linkage" can also serve as an important strategy for achieving solutions to a problem. This means that an actor can make a solution of an issue that is of concern to another actor dependent on the solution of an issue that is important to oneself.

Sixth, member states must ensure the establishment of intergovernmental commissions following the conclusion of framework agreements. These commissions are the sole responsibility of member states and they must be effectively and efficiently financed and manpowered. This will enable these commissions to adequately address the management, sustainability and utilisation of water-related issues. Furthermore, such commissions offer good platforms for national governments, lower level governments, water users, local populations, and non-governmental organisations (NGOs) to meet and discuss issues. Sharing data and information is crucial in collectively identifying, prioritising and addressing issues.

And lastly, another long-term solution to de-escalating tensions and fostering cooperation is through participatory water management. This simply means the involvement of the public in management issues. For instance, 
individual farmers are mostly ignored. However, this can be redressed by including lower levels of government in management issues. These levels of government are much closer to individual farmers, water users and NGOs at local levels. Subsequently, their participation at these levels will eventually be scaled up to higher levels of government, and thus ultimately reaching respective intergovernmental commissions. Article 33 of the UN Charter, for instance, contains an extensive, but not exhaustive list of dispute settlement techniques available to states. These include negotiation, inquiry, mediation, conciliation, arbitration, judicial settlement, and resort to regional agencies or arrangements.

\section{LIST OF SOURCES}

Aich, V, B Koné, F Hattermann and E Paton 2016. "Time series analysis of floods across the RNB", Water 8(165):3.

Amadou, A, GD Abdouramane, S Ousmane, SS Ibrah and K Sittichok 2014. "Changes to flow regime on the RNB at Koulikoro under a changing climate", Hydrological Sciences Journal, DOI: https://dx.doi.org/10.1080/02626667.2014. 916407.

Andersen, I, O Dione, M Jarosewich-Holder and J Olivry 2005. "The RNB: A vision for sustainable management", The International Bank for Reconstruction and Development/The World Bank, Washington, D.C.

Ayibotele, NB 2008. "West Africa - IWRM in the RNB", Case \#46, Accra.

Ayuba, HK 2016. "Environmental risks and developmental challenges confronting river Niger and its basin". Paper presented at the $8^{\text {th }}$ annual meeting of the African Organization of Supreme Audit Institutions Working Group on Environmental Auditing (Afrosai-wgea), 12-16 September, Abuja.

Axelrod, R and RO Keohane 1985. "Achieving cooperation under anarchy: Strategies and institutions", World Politics 38(1), October:226-254. https://doi. org/10.2307/2010357

Blumstein, S 2016. "Calming the waters: Why we need to better integrate climate and water policy", New Security Beat, 23 August, <https://www.newsecuritybeat. org/2016/08/calming-waters-integrate-climate-water-policy/>, accessed 1 March 2017.

Brels, S, D Coates, and F Loures 2008. "Transboundary water resources management: The role of international watercourse agreements in implementation of the CBD", Secretariat of the CBD Technical Series 40, Montreal: Convention on Biological Diversity. 
Cabot, C 2017. Climate change, security risks and conflict reduction in Africa: A case study of farmer-herder conflicts over natural resources in Cote d'Ivoire, Ghana and Burkina Faso 1960-2000. Berlin: Springer-Verlag. https://doi. org/10.1007/978-3-642-29237-8

Centre for Ecology and Hydrology 2017. "Niger River Basin", <http://www. waterandclimatechange.eu/river-basin/niger>, accessed 1 February 2017.

Diamond, K 2011. "Climate change, water, and conflict in the RNB", New Security Beat, 13 December, <https://www.newsecuritybeat.org/2011/12/climate-changeuncertainty-and-conflict-in-the-niger-river-basin/>, accessed 20 February 2017.

Diarra, ST 2011. "West Africa: RNB under pressure from dams", Inter Press Service (IPS), 31 October, <http://www.ipsnews.net/2011/10/west-africa-nigerriver-under-pressure-from-dams/>, accessed 23 February 2017.

Food and Agriculture Organisation of the United Nations (FAO) 2002. "Africa Region - Reversing land and water degradation trends in the RNB", UNDP, World Bank.

Gao, Y 2010. "Transboundary water governance in the Volta River Basin", $<$ https://wikis.uit.tufts.edu/confluence/display/aquapedia/Transboundary+Water+ Governance+in+the+Volta+River+Basin>, accessed 23 February 2017.

Godana, BA 1985. Africa's shared water resources. London: Fances Pinter.

Goulden, M and R Few 2011. "Climate change, water and conflict in the RNB", USAID, December.

Homer-Dixon, TF 1999. Environment, scarcity, and violence. Princeton, New Jersey: Princeton University Press.

International Environmental Agreement (IEA) 2016. "Revised Convention creating the Niger Basin Authority", <https://iea.uoregon.edu/treaty-text/1980nigerbasinauthorityentxt>, accessed 23 February 2017.

IRIN News 2000. "Focus on renewed tension with Mauritania", 8 June, <http:// www.irinnews.org/feature/2000/06/08/irin-focus-renewed-tension-mauritania>, accessed 23 February 2017.

IRIN News 2015. "International Court rules that main disputed island belongs to Niger not Benin", 12 July, <http://www.irinnews.org/report/55426/beninniger-international-court-rules-main-disputed-island-belongs-niger-not-benin>, accessed 23 February 2017. 
Jagow-Schultz, T 2017. "Niger: Boomerang River in Sub-Saharan Africa", World Wide Fund For Nature, <http://wwf.panda.org/about_our_earth/about_ freshwater/ rivers/niger/>, accessed 1 February 2017.

Keohane, RO 1984. After hegemony: Cooperation and discord in the world political economy. Princeton, New Jersey: Princeton University Press.

Keohane, RO 1989. International institutions and state power: Essays in International Relations Theory. Boulder, CO: Westview Press.

Keohane, RO and JS Nye 1977. Power and interdependence. Boston: Little, Brown.

Kistin, EJ 2012. "Critiquing cooperation: Transboundary water governance and adaptive capacity in the Orange-Senqu Basin", Journal of Contemporary Water Research and Education 149, December.

Krasner, SD, 1983. International regimes. Ithaca, NY: Cornell University Press.

Kukk, C and D Deese 1996. "At the water's edge: Regional conflict and cooperation over fresh water", UCLA Journal of International Law and Foreign Affairs 21(1):22.

Lindemann, S 2009. "Success and failure of international river basin management: The case of Southern Africa". In: HG Brauch, UO Spring, J Grin, C Mesjasz, P Kameri-Mbote, NC Behera, B Chourou and H Krummenacher (eds), Facing global environmental change: Environmental, human, energy, food, health and water security concepts, Hexagon Series on Human and Environmental Security and Peace 4:700-701. https://doi.org/10.1007/978-3540-68488-6_53

Lipson, C 1984. "International cooperation in economic and security affairs", World Politics 37(1), October. https://doi.org/10.2307/2010304

London School of Economics and Political Science (LSE) 2015. "The Global Climate Legislation Study: Nigeria", Grantham Research Institute on Climate Change and the Environment, 7 December, <http://www.Ise.ac.uk/ Granthamlnstitute/legislation/countries/nigeria/>, accessed 23 February 2017.

Mahé, G, G Liénou and O Adeaga 2009. "Water availability and access”, BFP Niger WP2.

McKinney, D 2012. "Transboundary water resources: Niger Basin", <http:// www.ce.utexas.edu/prof/mckinney/ce397/Topics/Niger/Niger.htm>, accessed 23 February 2017. 
Michel, D and R Passarelli 2014. "The climate wars are already here", Foreign Policy, 17 December, <http://foreignpolicy.com/2014/12/17niger-river-basinclimate-wars-are-already-here/>, accessed 3 February 2017.

Milner, H 1992. "International theories of cooperation among nations: Strengths and weaknesses", World Politics 44(3):466-496. https://doi.org/10.2307/2010546

National Mirror 2016. "Stakeholders in fresh move to tackle problems of Niger Basin Authority, 31 May, <http://nationalmirroronline.net/new/stakeholders-infresh-move-to-tackle-problems-of-niger-basin-authority/>, accessed 21 February 2017.

Niasse, M s.a. "The Niger Basin Authority", SHARE Toolkit: Case studies. IUCN Water Programme, <https://www.iucn.org/sites/dev/files/import/downloads/niger. pdf>, accessed 23 February 2017.

Okoth-Owiro, A 2004. "The Nile Treaty: State succession and international treaty commitments. A case study of the Nile Water Treaties, Occasional Papers, East Africa, Nairobi.

Olomoda I 2002. "Integrated water resources management: The Niger Basin Authority's experience". In: S Castelein (ed.), From conflict to co-operation in international water resources management: Challenges and opportunities. UNESCO-IHE Institute for Water Education International Conference Proceedings, 20-22 November. Delft, pp. 13-22.

Raadgever, T 2005. "Transboundary river basin management - State-of-the-art review on transboundary regimes and information management in the context of adaptive management", Centre for River Basin Administration, Delft University of Technology, November.

Raadgever, GT, E Mostert, N Kranz, E Interwies and JG Timmerman 2008. "Assessing management regimes in transboundary river basins: Do they support adaptive management?", Ecology and Science 13(1):5. https://doi.org/10.5751/ ES-02385-130114

Sahel Standard 2015. "War looms between Nigeria, Niger over River Niger", 4 May, <http://sahelstandard.com/index.php/2015/05/04/war-looms-betweennigeria-niger-over-river-niger/>, accessed 23 February 2017.

Talbi, A 2013. "1 River basin, 9 countries, 1 vision", The Water Blog - World Bank Blogs, 20 March, <http://blogs.worldbank.org/water/1-river-basin-9-countries-1vision>, accessed 23 February 2017. 
United Nations Department of Economic and Social Affairs (UNDESA) 2015. "International decade for action water for life 2005-2015", <http://www.un.org/ waterforlifedecade/water_cities.shtml>, accessed 1 March 2016.

United Nations Environment Programme (UNEP) 2010. "Africa water atlas", Division of Early Warning and Assessment (DEWA), Nairobi.

United Nations 1967. "1964 Agreement Concerning the RNB Commission and the Navigation and Transport on the River Niger", Treaty Series 587-3(8507), 25 November.

United Nations 1984. "1980 Convention Creating the Niger Basin Authority (with Protocol Relating to the Development Fund of the Niger Basin)", Treaty Series 1346(22675), 13 January.

Waterwiki.net 2009. "Niger Basin Authority", 17 October, <http://waterwiki.net/ index.php?title=Niger_Basin_Authority>, accessed 23 February 2017.

Wetlands International Africa 2012. "The RNB and its deltas", <http://africa. wetlands.org/Whatwedo/NigerRiverandDeltas/tabid/2944/language/en-GB/ Default.aspx>, accessed 1February 2017.

Wolf, AT 1998. "Conflict and cooperation along international waterways", Water Policy 1:261. https://doi.org/10.1016/S1366-7017(98)00019-1

World Bank 2015. "In the Niger Basin, countries collaborate on hydropower, irrigation and improved water resource management", 4 March, <http://www. worldbank.org/en/news/feature/2015/03/04/niger-basin-countries-collaborate-onhydropower-irrigation-and-improved-water-resource-management>, accessed 23 February 2017.

World Hunger 2016. "World hunger and poverty facts and statistics", <http:// www.worldhunger.org/2015-world-hunger-and-poverty-facts-and-statistics/>, accessed 1 March 2017.

Worldometers 2017a. "Nigeria population", <http://www.worldometers.info/worldpopulation/nigeria-population/>, accessed 1 March 2017.

Worldometers 2017b. "Mali population", <http://www.worldometers.info/worldpopulation/mali-population/>, accessed 1 March 2017.

Worldometers 2017c. "Niger Population", <http://www.worldometers.info/worldpopulation/niger-population/>, accessed 1 March 2017. 
Mahlakeng and Solomon - An analysis of regime capacity

Youssef, P 2016. "Violence around Lake Chad is leading nowhere - just deepening divides", The Guardian, 30 June, <https://www.theguardian.com/ global-development/2016/jun/30/violence-around-lake-chad-is-leading-nowherejust-deepening-divides>, accessed 23 February 2017. 